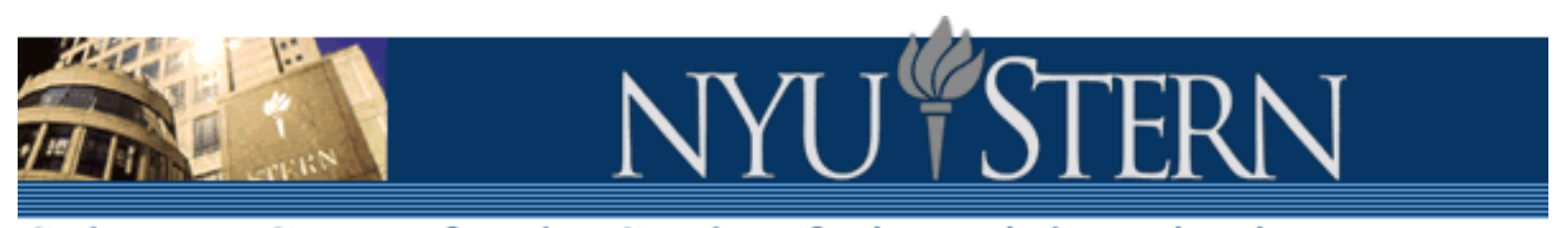

Salomon Center for the Study of Financial Institutions

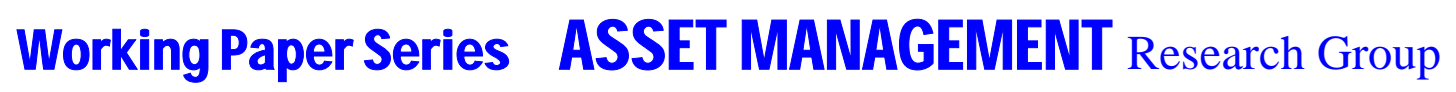

CAN MUTUAL FUND MANAGERS PICK STOCKS?

EVIDENCE FROM THEIR TRADES PRIOR TO EARNINGS ANNOUNCEMENTS

\author{
Malcolm Baker \\ Lubomir Litov \\ Jessica A. Wachter \\ J effrey Wurgler
}

SC-AM-05-02 


\title{
Can mutual fund managers pick stocks? Evidence from their trades prior to earnings announcements ${ }^{*}$
}

\author{
Malcolm Baker \\ Harvard Business School and NBER \\ mbaker@hbs.edu \\ Lubomir Litov \\ NYU Stern School of Business \\ llitov@stern.nyu.edu \\ Jessica A. Wachter \\ University of Pennsylvania Wharton School and NBER \\ jwachter@wharton.upenn.edu \\ Jeffrey Wurgler \\ NYU Stern School of Business and NBER \\ jwurgler@stern.nyu.edu
}

February 16, 2005

\begin{abstract}
We measure the stock-picking skill of mutual fund managers based on the returns realized around the subsequent earnings announcements of the stocks that they hold and trade. Relative to standard methodologies, this approach exploits the most informative segments of the returns data and ameliorates the joint hypothesis problem inherent in tests of stock-picking skill. Consistent with skilled trading, we find that, on average, stocks that funds buy earn significantly higher returns at subsequent earnings announcements than stocks that they sell. According to our measures of skill, certain funds perform persistently better than others, and the best performers tend to have a growth objective, large size, high turnover, and use incentive fees to motivate managers.
\end{abstract}

\footnotetext{
* We thank Marcin Kacperczyk, Andrew Metrick, Lasse Pedersen, Robert Stambaugh, and seminar participants and New York University and Yale University for helpful comments. We thank Christopher Blake and Russ Wermers for assistance with data. Baker gratefully acknowledges financial support from the Division of Research of the Harvard Business School.
} 


\title{
Can mutual fund managers pick stocks? Evidence from their trades prior to earnings announcements
}

\author{
February 16, 2005
}

\begin{abstract}
We measure the stock-picking skill of mutual fund managers based on the returns realized around the subsequent earnings announcements of the stocks that they hold and trade. Relative to standard methodologies, this approach exploits the most informative segments of the returns data and ameliorates the joint hypothesis problem inherent in tests of stock-picking skill. Consistent with skilled trading, we find that, on average, stocks that funds buy earn significantly higher returns at subsequent earnings announcements than stocks that they sell. According to our measures of skill, certain funds perform persistently better than others, and the best performers tend to have a growth objective, large size, high turnover, and use incentive fees to motivate managers.
\end{abstract}




\section{Introduction}

Can mutual fund managers pick stocks that "beat the market”? This question has long interested economists due to its enormous practical implications for millions of investors, who currently hold over \$3 trillion in U.S. corporate equities through mutual funds according to the Flow of Funds data, as well as for the light it sheds on securities market efficiency. But despite many attempts to answer this question, no consensus has emerged. ${ }^{1}$

In this paper, we develop a simple new methodology to measure stock-picking skill by mutual fund managers. The basic idea is to associate skill with the tendency to hold stocks that are about to enjoy high returns around their next quarterly earnings announcement, and to avoid stocks that are about to suffer low earnings announcement returns. This approach offers two key advantages over traditional tests which analyze managers’ returns over long horizons.

First, it has greater power to detect stock-picking skill. It exploits segments of the returns data—returns at earnings announcements—-that contain the most concentrated information about a firm’s earnings prospects, and hence about a fund manager’s skill at forecasting fundamentals. Also, Kothari and Warner (2001) offer simulation evidence that following fund managers' trades can considerably increase power to detect skill. Our approach utilizes both sources of power.

Second, one version of our methodology largely avoids the fundamental problem inherent in all performance tests, known as the joint-hypothesis problem. As Fama (1970) points out, performance must be adjusted for risk, and since the appropriate adjustment is unknown, the definition of "abnormal" performance is also unclear. So, one must usually maintain a hypothesis

\footnotetext{
${ }^{1}$ The literature examining mutual fund performance is vast. An abbreviated list of studies would include: Jensen (1968), Ippolito (1989), Malkiel (1995), and Carhart (1997), who conclude that mutual fund managers have little or no stock-picking skill; Grinblatt and Titman (1993), Daniel, Grinblatt, Titman, and Wermers (1997), Chen, Jegadeesh, and Wermers (2000), and Wermers (2000), who conclude that a significant degree of skill exists; and Lehman and Modest (1987) and Ferson and Schadt (1996), who emphasize the sensitivity of conclusions to methodological choices.
} 
about the validity of a risk-adjustment model in order to test a hypothesis about skill or market efficiency. But Brown and Warner (1985) show that inference based on daily returns around announcement dates is relatively insensitive to the risk-adjustment model. We apply this insight to performance evaluation. Just as stock returns around earnings announcements are mostly abnormal, regardless of the risk adjustment, a mutual fund's returns from holding that stock are also mostly abnormal. Furthermore, by comparing the subsequent earnings announcement returns on stocks that a given fund has been buying to those on the stocks that it has been selling, we can address even a strict version of the joint hypothesis critique which argues that required returns are systematically higher around earnings announcement dates.

The data set merges mutual funds' portfolio holdings with the respective returns that each holding realized at its next quarterly earnings announcement. The holdings are drawn from mandatory, periodic SEC N-30D filings which are tabulated by Thompson Financial. These data have been used by Grinblatt and Titman (1989) and Wermers (1999), among others. For each fund-date-holding observation in these data, we merge in the return that that stock earned in the 3-day window around its next earnings announcement. The sample covers 1980 through 2002 and contains 6.3 million fund-report date-holding observations with associated earnings announcement returns.

We begin the analysis by tabulating the earnings announcement returns realized by fund holdings, but our main results involve fund trades, since these tests best address the joint hypothesis problem. In particular, for each fund, we track the subsequent earnings announcement returns of the stocks on which it increases portfolio weight over the prior period and the stocks on which it decreases the portfolio weight. We then examine the subsequent earnings announcement returns on these stocks. 
Our main finding is that the average actively-managed mutual fund displays stockpicking skill in that the subsequent earnings announcement returns on its weight-increasing stocks is significantly higher than those on its weight-decreasing stocks. The difference is about 12 basis points over the three-day window around the quarterly announcement, or, multiplying by four, about 47 annualized basis points. The contrast between buys that initiate a fund's position in a stock and sells that close a position is even larger. While these numbers may not seem large in absolute terms, they apply to only a small fraction of the trading year. More important, they constitute unusually clean evidence of trading skill.

In addition to comparing the earnings announcement returns of stocks that funds buy and sell against each other, we also benchmark buys and sells against announcement returns earned by stocks with similar characteristics in that calendar quarter. We find that stocks bought by the average fund earn significantly higher subsequent announcement returns than matching stocks, while stocks sold earn lower returns. Thus, the average fund displays some skill in both its buying and selling behavior.

There are also some significant differences in the cross-section of mutual funds. Fund performance, measured using our metrics, tends to persist over time, and funds that do well are in general more likely to have a growth than income investment style, have a large net asset value, have a high turnover strategy, and use incentive fees to motivate managers. As we discuss, some of these cross-sectional results are consistent with results from earlier, long-horizon studies of fund performance, but our methodology allows us to make a more convincing claim that they reflect information-based trading.

One interesting policy question that we briefly address is whether the October 2000 introduction of SEC Regulation Fair Disclosure (“Reg FD”), which banned selective disclosure 
of material corporate information to preferred analysts and investors, has attenuated the ability of mutual fund managers to make information-based trades. In a comparison of fund manager performance before and after Reg FD, we find no clear patterns. We tentatively conclude that privileged access to information is unable to account for the stock-picking skill displayed by fund managers, and hence that Reg FD is unlikely to have eliminated their source of stockpicking skill.

A number of other recent papers also make use of earnings announcement returns to detect information-based trading. Seasholes (2004) examines foreign investors who trade in emerging markets. Ali, Durtschi, Lev, and Trombley (2004) examine institutional investors, broadly defined. Ke, Huddart, and Petroni (2003) follow trading by corporate insiders, and Christophe, Ferri, and Angel (2004) follow short sellers. Some differences with these papers include the fact that we stress the potential of this approach to address the joint hypothesis problem, and that we apply it to the study of individual mutual fund managers, a group of particular interest. We note other differences in the text.

In summary, this study presents fairly clear evidence that mutual fund managers do have some stock-picking skill. A caveat is that the methodology we employ, precisely because it uses a subset of the total returns data and a particular, well-defined notion of "skill," is not suited to measuring the total abnormal returns earned by mutual fund managers, or to addressing whether such returns are large enough to cover the fees fund managers charge. Rather, the advantage of the approach is that it puts a reliable lower bound on the portion of returns due to stock-picking skill; notably, this lower bound is significantly positive.

The paper proceeds as follows. Section II presents data. Section III presents empirical results. Section IV summarizes and concludes. 


\section{Data}

\section{A. Data set construction}

The backbone of our data set is the mutual fund holdings data from Thomson Financial (also known as CDA/Spectrum S12). Thomson's main source is the portfolio snapshot contained in the N-30D form each fund periodically files with the SEC. Prior to 1985, the SEC required each fund to report its portfolio quarterly, but starting in 1985 it required only semiannual reports. ${ }^{2}$ The exact report dates are set by the fund as suits its fiscal year. At a minimum, the Thomson data give us semiannual snapshots of all equity holdings for essentially all mutual funds. A sample fund-report date-holding observation is as follows: Fidelity Magellan, as of March 31, 1992, held 190,000 shares of Apple Computer. Wermers (1999) describes this data set in detail. We extract all portfolio holdings reported between the second quarter of 1980 and the third quarter of 2002.

To these holdings data, we merge in earnings announcement dates from the CRSP/Compustat merged industrial quarterly database. Specifically, for each fund-report dateholding observation, we merge in the first earnings announcement date that follows that holding's report date. ${ }^{3}$ We drop observations for which we can find no earnings announcement date within 90 days after the report date.

Next we add stock returns around each earnings announcement. From CRSP, we merge in the raw returns over the $[-1,+1]$ trading day interval around each announcement. We define a

\footnotetext{
${ }^{2}$ In February 2004, the SEC decided to return to a quarterly reporting requirement.

${ }^{3}$ Prior to this merge, we create placeholder observations for "liquidating” observations in the holdings data set, i.e. situations in which no holdings of a given stock are reported in the current report date but positive holdings were reported at the prior report date. This allows us to examine whether closing a position entirely portends especially poor earnings announcement returns.
} 
market-adjusted event return MAR as the raw announcement return minus the contemporaneous return on the CRSP value-weighted market index. We also define a benchmark-adjusted event return BAR as the raw return minus the average $[-1,+1]$ earnings announcement return on stocks of similar book-to-market, size, and momentum that also announced earnings in the same calendar quarter as the holding in question. Other than the fact that (for reasons described below) we define "momentum" as momentum of past earnings announcement returns, not total returns, our approach is similar to that in Daniel et al. (1997). ${ }^{4}$ We exclude fund-report dates that do not have at least one benchmark-adjusted earnings announcement return; our results are unchanged if we restrict attention to fund-report dates containing at least 10 or at least 20 such returns.

For a subset of the remaining observations, we can obtain fund characteristics data. Russ Wermers and WRDS provided links between the Thomson holdings data and the CRSP mutual fund database, as described in Wermers (2000). From the CRSP mutual fund data we take investment objective codes as well as total net assets, turnover, and expense ratios. ${ }^{5}$ Christopher Blake shared the data on incentive fees as studied in Elton, Gruber, and Blake (2003). These data, originally from Lipper, cover through 1999. Fee structures are similar across the funds that use them, so we simply study whether the fund has an incentive fee in place.

\footnotetext{
${ }^{4}$ Specifically, we form the value-weighted average earnings announcement return for each of 125 benchmark portfolios (5x5x5 sorts on book-to-market, size, and earnings announcement return momentum) each calendar quarter. Book-to-market is defined following Fama and French (1995). Market value of equity is computed using the CRSP monthly file as the close times shares outstanding as of December of the calendar year preceding the fiscal year data. The book-to-market ratio is then matched from fiscal years ending in year (t-1) to earnings announcement returns starting in July of year ( $t$ ) and from fiscal years ending in (t-2) to earnings announcement returns in January through June of year (t). Size is matched from June of calendar year (t) to returns starting in July of year (t) through June of year $(t+1)$. Momentum is the average return over the past four earnings announcements. The breakpoints on book-to-market and size are based on the NYSE as reported on Ken French's website. The benchmark portfolios include only stocks with positive book equity that are ordinary common stocks (CRSP share codes 10 or 11). It is impractical to do a $5 \times 5 \times 5 \times 5$ sort and thus control for overall return momentum, but we have found that switching the earnings announcement momentum control with an overall momentum control leads to similar results.

${ }^{5}$ Turnover data for 1991 is missing in the CRSP database. Also, CRSP sometimes reports several classes of shares for a given fund, corresponding to different fee structures for the same portfolio of stocks (e.g. A, B, C, institutional, no-load). In these cases, we take the highest reported value for turnover across all classes to use as the value for turnover, and the value-weighted average of expenses across all classes as the value for the expense ratio.
} 
Finally, we apply a set of screens to obtain an appropriate sample. Based on keywords in the name of the fund and on reported investment objectives, we exclude funds that cannot be predominantly characterized as actively managed U.S. equity funds, such as index, bond, international, and precious metals funds. We exclude funds with less than $\$ 10$ million in net asset value. We also exclude each fund's first report date, as some of our analysis requires lagged portfolio weights.

\section{B. Summary statistics}

Our final sample consists of 6.3 million fund-report date-holding observations with associated earnings announcement returns, spread across 75,263 fund-report dates. Table 1 shows summary statistics. The first column shows that the number of funds has increased dramatically over the sample period. Almost half of the useable fund-report dates are in the last five years of the sample.

The next three columns show the distribution of investment objectives. A consistent, comprehensive set of objectives is not available. CDA classifications are available from 1980 through 1992, with a methodology change in 1990. S\&P provide a broader set of objectives, but do not start until 1992. By combining these data we obtain a fairly consistent classification for growth, growth \& income, and income styles. The remaining funds fall mainly into balanced, sector, or total return categories. ${ }^{6}$

\footnotetext{
${ }^{6}$ From 1980 through 1989, the CDA investment objective is available for 76 percent of the sample fund-report dates. 92 percent of the non-missing observations are categorized as growth (44 percent), maximum capital gains (21 percent), growth and income (19 percent), and income (9 percent). In 1990 and 1991, the CDA investment objective is available for 79 percent of the sample. We group the first two into growth funds. 86 percent of the nonmissing observations are categorized as maximum capital gains (14 percent), long-term growth (38 percent), small capitalization growth (4 percent), growth and current income (23 percent), equity income (4 percent), and flexible income (3 percent). We group the first three categories into growth funds, and the last two into income funds. The other significant classifications are balanced and sector. From 1992 through 2002, the S\&P investment objective is available for 73 percent of the sample. 76 percent of the nonmissing observations are categorized as aggressive
} 
The next five columns show fund holdings and trading activity. For the average fundreport date we are able to identify and benchmark a total of 84.0 holdings. Portfolio breadth has increased steadily over time. On average, 51.7 holdings receive an increase in weight in the portfolio over that in the prior report, of which 20.5 are new first buys. 50.8 holdings receive a decrease in weight, on average, and 18.5 of these decrease to zero weight. We also distinguish the performance of first buys and last sells under the logic that these are guaranteed to reflect a deliberate trading decision; by contrast, generic weight shifts can be caused by changes in overall fund size. ${ }^{7}$

The last columns summarize fund characteristics. Fund size is computed as the total market value of the fund's reported equity holdings for which we also have earnings announcement return data. Average size peaks at \$84.1 million in 2000. Turnover is available for 71 percent of the sample, averages 95.1 percent per year for the sub-sample for which it is available, and increases 37 percentage points over the sample period. The expense ratio is available for 76 percent of the sample, averages 1.25 percent per year for the sub-sample for which it is available, and increases by 45 basis points over the period. The last column shows the percentage of funds using incentive fees. In the average year for which we have data, 2.2 percent of funds use fees. Elton et al. (2003) report that these funds account for around 10 percent of all mutual fund assets. Since some of these characteristics display trends, we will sort funds into quintiles within each reporting period when we study the relationship between characteristics and performance.

growth (22 percent), long-term growth (32 percent), growth and income (18 percent) and income (5 percent). We group the first two categories into growth funds. The other significant classifications are balanced, sector, and total return.

${ }^{7}$ Another natural way to define trading activity is to track changes in reported shares across report dates (adjusting for splits). Not surprisingly, the results for this measure tend to be bracketed by those for generic weight shifts and teminal/initiating trades, and so we omit them for brevity. 


\section{Results}

\section{A. Earnings announcement returns of holdings}

We start by summarizing the average performance of mutual fund holdings around earnings announcements. While we are more interested in subsequent earnings announcement performance of funds' trades, not their holdings, starting with an analysis of the latter allows us to develop the methodology step by step.

The first column of Table 2 reports the average raw return over the three-day window around earnings announcement dates. Specifically, we take the equal-weighted average earnings announcement return for each fund-report date, annualize it (multiplying by 4 quarters), average these across all fund-report dates within that year, and, finally, average the yearly averages. That is, the average raw return of 1.08 is:

$$
\text { Return }=4 \cdot \frac{1}{23} \sum_{1980}^{2002} \frac{1}{N} \sum_{i} \frac{1}{K_{i}} \sum_{j} \sum_{-1}^{1} r_{i j, t},
$$

where $i$ indexes mutual funds from 1 to $N, j$ indexes the holdings of mutual fund $i$ from 1 to $K_{i}$, and $t$ measures days around the earnings announcement of stock $i j .{ }^{8}$

This procedure treats each annual average as a single data point in computing an overall average and standard error at the bottom of the table. The standard deviation of the annual averages is 1.34. Combining this with the average return of 1.08 and the sample size of 23 gives a t-statistic of 3.9. This approach to inference is in the spirit of Fama and MacBeth (1973). Taking simple averages across the pooled data, which gives more weight to the last five years of the sample, leads to similar conclusions.

\footnotetext{
${ }^{8}$ Because the sample starts in the second quarter of 1980 and ends in the third quarter of 2002, the average return for 1980 is for the last three quarters while the average return for 2002 is the first three quarters.
} 
The second and third columns adjust the raw returns. The second column reports marketadjusted returns (MAR), where we subtract the CRSP value-weighted market return over the earnings announcement window. The average MAR of 0.52 is:

$$
\text { MAR }=4 \cdot \frac{1}{23} \sum_{1980}^{2002} \frac{1}{N} \sum_{i} \frac{1}{K_{i}} \sum_{j} \sum_{-1}^{1}\left(r_{i j, t}-r_{m, t}\right) .
$$

Based on the standard deviation of the annual averages, the t-statistic here is 3.5 .

The third column shows a benchmark-adjusted return (BAR), where each holding is matched to one of 125 benchmark portfolios by quintiles of size, book-to-market, and earnings announcement return momentum. That is, the benchmark portfolios contain the value-weighted, matched-firm average earnings announcement return in that calendar quarter. The average BAR of 0.01 is then:

$$
\mathrm{BAR}=4 \cdot \frac{1}{23} \sum_{1980}^{2002} \frac{1}{N} \sum_{i} \frac{1}{K_{i}} \sum_{j}\left(\sum_{t=-1}^{1} r_{i j, t}-\sum_{l} w_{l} \sum_{s_{l}=-1}^{1} r_{l, s_{l}}\right),
$$

where $l$ indexes the matched firms within the quarter where $t$ equals zero, $w_{l}$ is the market value weight of stock $l$ in the characteristics-matched portfolio, and $s_{l}$ measures days around the earnings announcement of stock $l$ within the matched quarter. Note that in Eq. (3) the earnings announcement return and the benchmark do not overlap exactly.

BAR controls for known associations between earnings announcement returns, firm characteristics, and prior announcement returns. Chari et al. (1988) and La Porta et al. (1997) find that small, high book-to-market firms tend to have higher announcement returns, and Bernard and Thomas (1989) find that earnings announcement returns are positively autocorrelated. BAR controls for these effects. And in allowing the benchmark return to vary from quarter to quarter, it also controls for a "good earnings quarter for small value stocks," for example, and thus more precisely picks up stock-selection skill. Of course, it would be a valuable skill to be able to predict abnormal returns at the "style" level, or to recognize and exploit the 
positive autocorrelation in abnormal announcement returns. BAR does not pick up these dimensions of skill, so it is conservative. But a conservative measure of stock-picking ability seems appropriate given the goal of our approach, which is to establish a sturdy lower bound on stock-picking skill.

Table 2 shows that mutual funds earn, on an equal-weighted average basis, 1.08 percent per year from the twelve trading days surrounding their holdings' earnings announcements. This exceeds the corresponding market return by 52 basis points, and so is an outsize average return compared to non-announcement days. The raw annualized announcement return earned by the average fund manager is not significantly larger than that earned on a portfolio of firms with matching characteristics and prior earnings announcements: the average BAR is an insignificant 6 basis points. The second set of columns show that similar conclusions obtain when holdings are value-weighted in each fund-report date.

To the extent that the BAR accurately measures the unexpected release of information, then the average mutual fund, as measured by its holdings, does not appear to possess stockpicking ability. This would be consistent with the message of Jensen (1968) and many studies since. But the conclusion that mutual fund managers do not have skill is clearly premature. A subset may have skill, even if the average does not. Or, funds may hold many stocks for which they once had good information but now retain because of transaction costs or a capital gains tax overhang, an effect which would greatly reduce the power of our tests. We consider these possibilities next. 


\section{B. Fund characteristics and earnings announcement returns of holdings}

We next look for patterns in the cross-sectional distribution of holdings-based performance measures. Under the null hypothesis of no skill, none should be apparent. The first dimension we sort funds on is past performance. The persistence of performance has been studied previously, in long-horizon returns, by Hendricks, Patel, and Zeckhauser (1993), Brown and Goetzmann (1995), and others. Do the same funds that had high earnings announcement alphas in the past continue to have them in the future?

Panel A of Table 3 shows the results of tests for persistence. We sort stocks each year from 1983 to 2002 into quintiles based on the average announcement return, or the average BAR alpha, that they earned over their previous eight announcements. We then compare the subsequent annualized announcement returns and BAR alphas of funds in the top quintile of prior performance to those in the bottom quintile. The first columns show the mean equalweighted return and BAR alpha, as well as t-statistics.

There is significant persistence in the earnings announcement alphas both in raw and benchmark-adjusted returns. When sorted by prior equal-weighted BAR, the subsequent equalweighted BAR rises monotonically. The difference between the top and bottom quintiles is a significant 43 basis points per year. The fact that persistence is present in BAR, i.e., even after adjustments are made for size, book-to-market, and announcement return momentum, indicates that performance persistence cannot be explained by persistence in characteristics-adjusted announcement returns alone. ${ }^{9}$ Value-weighted results display a similar but weaker pattern, suggesting it may be easier to pick future earnings winners among smaller stocks.

\footnotetext{
${ }^{9}$ This is where it is crucial to control for prior earnings announcements. In the absence of such a control, the Bernard and Thomas (1989) effect could lead to a spurious persistence.
} 
The remaining panels of Table 3 look at how performance is correlated with fund characteristics. Panel B considers investment objective, including growth, growth and income, and income styles. A clear pattern emerges. Growth funds earn higher earnings announcement returns than growth and income funds, which in turn earn higher returns than income funds. The same pattern is as strong, or stronger, in BAR alphas. Indeed, the BAR on the portfolio of growth funds is positive, while the BAR on income and growth and income funds is negative. Wald tests (unreported) reject both that the average return for each category is equal to zero and that the average return is equal across categories. Comparing each style to the equal-weighted average of the other two reveals that income funds perform significantly worse than growth and growth and income categories. Similarly, growth funds perform significantly better. These results are consistent with Grinblatt and Titman $(1989,1993)$ and Daniel et al. (1997), who also find the most evidence of stock-selection ability among growth funds, and thus indicate that these earlier patterns from long-horizon studies can be attributed to information-based trading with some confidence.

Panel C examines returns by fund size quintiles. There is a hint that performance around earnings announcements increases with fund size; specifically, the smallest quintile does worse than any of the larger quintiles. In unreported results, we find that the significance of this pattern is stronger if one uses the number of holdings to measure fund size. The finding that small funds make superior trades differs from Chen, Hong, Huang, and Kubik (2004), who study the longhorizon returns of large and small funds.

So far, we have seen that funds with high earnings announcement alphas can be identified from past performance, style, and, to some extent, size. One possibility is that differential performance is associated with, or perhaps facilitated by, higher expenses. This is not the case. 
Expense ratios bear little relation to performance. We omit a tabular presentation for brevity, but are results are consistent with, e.g., Chevalier and Ellison (1999), who also find no positive relationship between raw performance and expenses. In contrast, there is strong evidence that high earnings announcement alphas are associated with high turnover. Panel D shows that across all four performance measures, funds in the highest turnover quintile have significantly higher performance.

Finally, Panel E considers the effect of incentive fees. By all measures of earnings announcement alpha, funds with incentive fees perform better. The difference is statistically significant for three measures. This reinforces the earlier long-horizon results of Elton, Gruber, and Blake (2003), and again ties them much more convincingly to information-based trading.

\section{Earnings announcement returns following trades}

While Fama (1991) argues that the use of earnings announcement returns is probably about the closest one can come to solving the joint hypothesis problem, one can still argue with the holdings-based methodology on these grounds. If rationally expected returns at earnings announcements are different from those on other days — in particular, the positive average MAR in Table 2 suggests they may be larger - then the holdings-based methodology cannot fully resolve the joint hypothesis problem. ${ }^{10}$

Fortunately, a methodology based on fund trades allows for a simple solution. We can compare the subsequent earnings announcement returns of stocks that the fund buys with those

\footnotetext{
${ }^{10}$ On the other hand, it is difficult to see why risk around earnings announcements would deserve extra compensation in any standard rational asset pricing model, since earnings news is mainly idiosyncratic. Also, Bernard and Thomas (1989) find that earnings announcement returns are positively autocorrelated, suggesting that forces other than risk premia, such as underreaction, play an important role. It is not clear why the marginal investor could be sophisticated enough to put a risk premium around announcements but naïve enough to systematically underreact to the information actually being released.
} 
that it sells. Even if there is such a thing as an earnings announcement risk premium, it will be differenced away in the comparison between a fund's buys and its sells. At the same time, this approach may also increase power. Trading involves transaction costs and perhaps the realization of capital gains, so it is a stronger signal than simply continuing to hold. Thus, a trades-based methodology offers a powerful and clean test of stock-picking skill by mutual fund managers. ${ }^{11}$

Table 4 repeats the analysis from Table 2 but computes announcement returns only for holdings whose portfolio weight changed between the current and the previous report dates. The first three pairs of columns show equal-weighted raw and benchmark-adjusted returns for holdings whose weight increased or decreased. The second three pairs of columns focus only on first buys, i.e., when a fund moves from zero to a positive holding of the stock, and last sells, i.e., when a fund closed out the position.

Table 4 contains the main results of the paper. Stocks in which funds have been increasing weight earn 20 annualized basis points more around their next earnings announcement than matched stocks. Also, stocks in which mutual funds have decreased their weight earn a significant 21 annual basis points less than matched stocks. Thus, the average mutual fund is successful both in buying subsequent outperformers and in selling subsequent underperformers. Both effects are significantly different from zero. Reflecting the combined influence of the two effects, the BAR of weight increases minus weight decreases is positive in 20 out of 23 years.

\footnotetext{
${ }^{11}$ Ali et al. (2004) find that increases in total institutional ownership predict higher earnings announcement returns. Our approach here differs in several respects. First, the N-30D data allow us to study performance of individual funds; Ali et al. study SEC 13F data, which are aggregated at the institutional investor level (e.g., mutual fund family). Second, the 13F data reported by Thompson Financial does not permit a reliable breakdown even among aggregates such as mutual fund families and other institutional investors of little interest to retail investors: many giant fund families, such as Fidelity, Schwab, and Eaton Vance, are classified in an "other" category along with college endowments, pension funds, private foundations, hedge funds, etc. Third, the Ali et al. results can in principle be driven by a single large institutional investor. Their results shed no clear light on trading by mutual fund managers individually or in general. Our performance metrics, on the other hand, are built from the individual mutual fund level, and allow us to study the average mutual fund manager.
} 
Trades that are "first buys" and "last sells" give an even clearer indication of skilled trading, as one might expect. The average mutual fund's first buys subsequently earn 34 basis points more than matching stocks, while its last sells subsequently earn 29 basis points less. Both effects are again highly significant, as is the overall difference between first buys and last sells.

Note that Table 5 also shows that the difference in raw announcement returns between buys and sells is quite close to the difference in BARs. This is not just a coincidence of the averages; the link is tight year after year. What it means is that the bulk of the total difference between buys and sells is due to picking winners and losers within characteristic groupings, not to rebalancing toward the characteristics that are associated with better subsequent announcement returns.

Overall, these results offer fairly striking evidence of stock-picking skill among mutual fund managers. Even the average mutual fund manager trades as if he has superior information about the earnings prospects of firms. While a direct comparison to Jensen (1968) is inappropriate, our results contrast with his oft-cited message that the average mutual fund underperforms. Our results complement the recent findings of Chen, Jegadeesh, and Wermers (2000). They document a gap between the long-horizon returns between the stocks that mutual funds buy and those they sell. The current methodology, by design, cannot shed light on the total returns to stock-picking skill. Its contribution lies in providing convincing evidence that at least a portion of total performance can be attributed to informed trading.

\section{Fund characteristics and earnings announcement returns following trades}

Table 5 reports the performance of trades according to fund characteristics. We starts with persistence. For each of the six trade-based BAR alpha measures and the six raw return 
measures, we sort funds into quintiles based on their previous performance over the past two years, and then tabulate their subsequent performance.

The results in Panel A show evidence of persistence, in particular for measures based on weight increases, weight decreases, or the difference. The gap between the BAR of the highest and lowest weight increase quintiles is a significant 37 basis points, and the gap for weight decreases is an even larger 60 basis points. (Recall that sorting across quintiles has the opposite interpretation for weight increases and decreases. For weight increases, high BAR indicate forecasting skill. For decreases, low BAR indicate skill.) However, there is little evidence of persistence in relative performance of first buys, last sells, and first buys minus last sells. A likely explanation is that classifications based on the performance of past first buys or last sells are very noisy, there being far fewer such trades than generic buys or sells.

The remaining panels sort on other fund characteristics. The effects are typically in the same direction as the earlier results based on holdings, but tend to be weaker. Panel B shows that growth funds once again appear to outperform income funds. Wald tests (unreported) reject the hypothesis of equality in most cases. Larger funds marginally outperform smaller funds, expense ratios do not matter (unreported), and turnover and incentive fees are weakly positively correlated with performance. In light of the much stronger results in Table 4, the main takeaway is that various categories of funds buy subsequent earnings winners and sell subsequent earnings losers, but there are also some differences across style and other characteristics. ${ }^{12}$

\section{E. $\quad \operatorname{Reg} F D$}

\footnotetext{
${ }^{12}$ An interesting question for future research is whether the personal characteristics and educational backgrounds of fund managers affect performance, as in Chevalier and Ellison (1999) or Bertrand and Schoar (2003).
} 
If one accepts the evidence in Table 4 that mutual fund managers can pick stocks to a certain degree, the follow-up question is how they do so. Clearly, this is very difficult to answer. The most obvious explanation is that they have a superior ability to assemble and interpret publicly available information. However, regulatory attention has recently focused on another possibility, the quasi-private information transmitted when corporate managers selectively disclose material information to preferred analysts and institutional investors before the public. In October 2000, SEC Regulation Fair Disclosure, popularly known as “Reg FD”, banned the practice of selective disclosure. ${ }^{13}$

One motivation for Reg FD was the observation that “... those who were privy to the information beforehand were able to make a profit or avoid a loss at the expense of those kept in the dark" (U.S. Securities and Exchange Commission (2000, p.2)). A simple way to test whether selective disclosure may have been important to the ability of mutual fund managers to pick stocks is to compare the earnings announcement performance of fund trades before and after Reg FD. If selective disclosure drives mutual fund managers' ability to pick stocks, the BAR of buys should drop (toward zero) and the BAR of sells should rise (toward zero) in the post-Reg FD era.

Table 4 allows for a quick evaluation of these hypotheses. It shows that the BAR of buys did indeed drop in 2001 and 2002 relative to earlier years. We have verified that the drop is statistically significant. While this is consistent with a selective disclosure effect, note that there is also a significant drop in the BAR of first buys. It seems unlikely that fund managers who are not current investors would be been in a position to benefit from selective disclosure. Furthermore, Table 4 shows that the BAR of sells also drops in 2001 and 2002. This drop is also statistically significant. But if mutual funds were indeed privy to quasi-private negative

\footnotetext{
${ }^{13}$ See Gomes, Gorton, and Madureira (2004) for a fuller discussion of the debates surrounding Reg FD, as well as empirical evidence that Reg FD increased analysts' earnings forecast errors and the volatility of stock returns around earnings announcements.
} 
information in the pre-Reg FD era, these returns should have risen, not become even more strongly negative.

Additional years of data will allow the post-Reg FD effects to be measured with more precision, but the current evidence seems best interpreted as year-to-year variation than as a Reg FD effect. If correct, this interpretation implies that our main results about mutual fund managers' abilities to pick stocks were not driven by selective disclosure, and thus were not eliminated by the passage of Reg FD.

\section{Summary}

Whether or not mutual fund managers can pick stocks is an important question for hundreds of economists and millions of investors. However, the question has remained hotly debated, with a number of studies arguing that fund managers are skilled and others arguing that they are not.

In this paper, we suggest a novel approach to measure stock-picking skill which offers some important advantages over prior studies. First, our approach uses segments of the returns data, returns around earnings announcements, that are especially informative about whether a fund manager was correct in her recent decisions to buy or sell. Second, a version of the methodology that follows the stocks that funds have been trading, not just passively holding, largely avoids the joint-hypothesis problem common to all studies of mutual fund manager skill based on performance over long return horizons. In sum, our approach is potentially more powerful while at the same time avoids the most serious interpretational problem faced by standard studies. 
We apply this methodology to study the universe of actively managed U.S. equity mutual funds between 1980 and 2002. We find fairly unambiguous evidence that fund managers do have at least some degree of stock-picking skill. In particular, the future earnings announcement returns on stocks that funds buy are, on average, considerably higher than the future announcement returns on stocks that they sell. Also, the stocks that funds buy perform significantly better at future earnings announcements than stocks with similar characteristics, while the stocks that funds sell perform significantly worse than matching stocks. Contrary to the oft-cited message of Jensen (1968), the results suggest that even the average mutual fund manager has some degree of stock-picking skill. 


\section{References}

Ali, Ashiq, Cindy Durtschi, Baruch Lev, and Mark Trombley, 2004, Changes in institutional ownership and subsequent earnings announcement abnormal returns, Journal of Accounting, Auditing, and Finance (forthcoming).

Bernard, Victor, and Jacob Thomas, 1989, Post-earnings announcement drift: Delayed price response or risk premium? Journal of Accounting Research 27 (Supplement), 1-36.

Bertrand, Marianne, and Antoinette Schoar, 2003, Managing with style: The effect of managers on firm policies, Quarterly Journal of Economics 118, 1169-1208.

Brown, Stephen J., and Jerold B. Warner, 1985, Using daily stock returns: The case of event studies, Journal of Financial Economics 14, 3-32.

Brown, Stephen J., and William N. Goetzmann, 1995, Performance persistence, Journal of Finance 50, 679-698.

Carhart, Mark, 1997, On persistence in mutual fund performance, Journal of Finance 52, 57-82.

Chari, V. V., Ravi Jagannathan, and Aharon R. Ofer, 1988, Seasonalities in securities returns: The case of earnings announcements, Journal of Financial Economics 21, 101-121.

Chen, Hsiu-Lang, Narasimhan Jegadeesh, and Russ Wermers, 2000, The value of active mutual fund management: An examination of the stockholdings and trades of mutual fund managers, Journal of Financial and Quantitative Analysis 35, 343-368.

Chen, Joseph, Harrison Hong, Ming Huang, and Jeffrey D. Kubik, 2004, Does fund size erode mutual fund performance? The role of liquidity and organization, American Economic Review (forthcoming).

Chevalier, Judith, and Glenn Ellison, 1999, Are some mutual fund managers better than others? Cross-sectional patterns in behavior and performance, Journal of Finance 54, 875-899.

Christophe, Stephen E., Michael G. Ferri, and James J. Angel, 2004, Short-selling prior to earnings announcements, Journal of Finance 59, 1845-1876.

Daniel, Kent D., Mark Grinblatt, Sheridan Titman, and Russ Wermers, 1997, Measuring mutual fund performance with characteristic-based benchmarks, Journal of Finance 52, 10351058.

Elton, Edwin J., Martin J. Gruber, and Christopher R. Blake, 2003, Incentive fees and mutual funds, Journal of Finance 58, 779-804.

Fama, Eugene F., 1970, Efficient capital markets: A review of theory and empirical work, Journal of Finance 25, 383-417. 
Fama, Eugene F., 1991, Efficient capital markets II, Journal of Finance 46, 1575-1617.

Fama, Eugene F., and James MacBeth, 1973, Risk, return, and equilibrium: Empirical tests, Journal of Political Economy 81, 607-636.

Ferson, Wayne E., and Rudi W. Schadt, 1996, Measuring fund strategy and performance in changing economic conditions, Journal of Finance 51, 425-461.

Gomes, Armando, Gary Gorton, and Leonardo Madureira, 2004, SEC Regulation Fair Disclosure, information, and the cost of capital, University of Pennsylvania working paper.

Grinblatt, Mark, and Sheridan Titman, 1989, Mutual fund performance: An analysis of quarterly portfolio holdings, Journal of Business 62, 393-416.

Grinblatt, Mark, and Sheridan Titman, 1992, The persistence of mutual fund performance, Journal of Finance 47, 1977-1984.

Grinblatt, Mark, and Sheridan Titman, 1993, Performance measurement without benchmarks: An examination of mutual fund returns, Journal of Business 66, 47-68.

Grinblatt, Mark, and Sheridan Titman, 1994, A study of monthly mutual fund returns and performance evaluation techniques, Journal of Financial and Quantitative Analysis 29, 419-444.

Hendricks, Darryll, Jayendu Patel, and Richard Zeckhauser, 1993, Hot hands in mutual funds: The persistence of performance, 1974-88, Journal of Finance 48, 93-130.

Ippolito, Richard A., 1989, Efficiency with costly information: A study of mutual fund performance, 1965-1984, Quarterly Journal of Economics 104, 1-23.

Jensen, Michael C., 1968, The performance of mutual funds in the period 1945-1964, Journal of Finance 23, 389-416.

Ke, Bin, Stephen Huddart, and Kathy Petroni, 2003, What insiders know about future earnings and how they use it: Evidence from insider trades, Journal of Accounting \& Economics $35,315-346$.

Kothari, S.P., and Jerold B. Warner, 2001, Evaluating mutual fund performance, Journal of Finance 56, 1985-2010.

La Porta, Rafael, Josef Lakonishok, Andrei Shleifer, and Robert W. Vishny, 1997, Good news for value stocks: Further evidence on market efficiency, Journal of Finance 52, 859-874. 
Lehman, Bruce, and David Modest, 1987, Mutual fund performance evaluation: A comparison of benchmarks and benchmark comparisons, Journal of Finance 42, 233-265.

Malkiel, Burton G., 1995, Returns from investing in equity mutual funds 1971 to 1991, Journal of Finance 50, 549-572.

Seasholes, Mark, 2004, Re-examining information asymmetries in emerging stock markets, University of California at Berkeley working paper.

U.S. Securities and Exchange Commission, August 10, 2000, Selective disclosure and insider trading, 17 CFR Parts 240, 243, and 249, Release Nos. 33-7881, 34-43154, IC-24599 (http://www.sec.gov/rules/final/33-7881.htm).

Wermers, Russ, 1999, Mutual fund herding and the impact on stock prices, Journal of Finance 54, 581-622.

Wermers, Russ, 2000, Mutual fund performance: An empirical decomposition into stock-picking talent, style, transactions costs, and expenses, Journal of Finance 55, p. 1655-1695. 
Table 1. Summary statistics. The sample is the intersection of the Spectrum Mutual Fund holdings database, Compustat, and CRSP. To be included in the sample, a mutual fund holding must have matched earnings announcement date and book value from CRSP, and a valid return, market value of equity (price times shares outstanding), past momentum (return from months $t-12$ through $t$-2), and three-day return in the earnings announcement window from CRSP. Portfolio holdings data cover 1980Q2 to 2002Q3. We compute terminal holdings for stocks that exit the portfolio. Where possible, we include the investment objective from the CRSP mutual fund database as determined by CDA Weisenberger or S\&P. The investment objective growth includes codes G, MCG, and LTG from CDA and LG, and AG from S\&P. The investment objective growth and income includes G-I and GCI from CDA and GI and IN from S\&P. The investment objective income includes I, IEQ, and IFL from CDA and IN from S\&P. We classify each holding as a weight increase or weight decrease. We also record those weight increases that are first buy (from zero to positive weight), and those weight decreases that are last sells (from positive weight to zero). We measure fund size as the total market value (price times shares outstanding) of its reported equity holdings; fund turnover and fund expense ratio from the CRSP mutual fund database; and incentive fees (whether or not the fund has such a structure) from Blake, Elton, and Gruber (2003) and Lipper. Turnover is missing in CRSP in 1991 and incentive fees are not available after 1999.

\begin{tabular}{|c|c|c|c|c|c|c|c|c|c|c|c|c|c|}
\hline \multirow[b]{2}{*}{ Year } & \multicolumn{4}{|c|}{ Fund-Report Date Observations } & \multicolumn{5}{|c|}{ Average Fund Activity } & \multicolumn{4}{|c|}{ Fund Characteristics } \\
\hline & All & Growth & $\begin{array}{r}\text { Growth\& } \\
\text { Income }\end{array}$ & Income & Holdings & $\begin{array}{r}\text { Weight } \\
\text { Increases }\end{array}$ & $\begin{array}{r}\text { Weight } \\
\text { Decreases }\end{array}$ & $\begin{array}{l}\text { First } \\
\text { Buys }\end{array}$ & $\begin{array}{l}\text { Last } \\
\text { Sells }\end{array}$ & $\begin{array}{r}\text { Size } \\
(\$ M)\end{array}$ & $\begin{array}{r}\text { Turnover } \\
(\%)\end{array}$ & $\begin{array}{r}\text { Expenses } \\
(\%)\end{array}$ & $\begin{array}{r}\text { Inc. Fees } \\
\text { (\% Yes) }\end{array}$ \\
\hline 1980 & 810 & 382 & 107 & 25 & 49.1 & 27.3 & 28.3 & 6.9 & 6.5 & 14.2 & 75.3 & 0.94 & 0.6 \\
\hline 1981 & 1,088 & 494 & 137 & 27 & 49.0 & 29.4 & 26.8 & 6.5 & 7.2 & 13.6 & 68.5 & 0.92 & 1.5 \\
\hline 1982 & 903 & 430 & 122 & 32 & 49.6 & 29.5 & 29.3 & 9.2 & 9.2 & 14.1 & 74.0 & 0.95 & 2.5 \\
\hline 1983 & 1,085 & 525 & 142 & 56 & 57.8 & 33.0 & 34.8 & 11.4 & 10.0 & 19.7 & 77.3 & 0.94 & 2.5 \\
\hline 1984 & 1,218 & 579 & 170 & 71 & 59.0 & 35.0 & 34.5 & 10.5 & 10.5 & 17.8 & 72.9 & 0.96 & 2.4 \\
\hline 1985 & 1,362 & 660 & 196 & 94 & 58.5 & 34.7 & 34.5 & 11.4 & 10.6 & 20.5 & 80.8 & 0.97 & 2.6 \\
\hline 1986 & 1,530 & 756 & 224 & 149 & 60.4 & 35.5 & 36.5 & 12.3 & 11.6 & 24.8 & 78.6 & 0.99 & 2.7 \\
\hline 1987 & 1,742 & 872 & 266 & 173 & 63.9 & 37.6 & 39.0 & 13.7 & 12.7 & 30.2 & 96.0 & 1.06 & 3.1 \\
\hline 1988 & 1,843 & 931 & 298 & 168 & 63.8 & 38.6 & 35.8 & 11.3 & 10.6 & 25.1 & 81.5 & 1.18 & 3.2 \\
\hline 1989 & 1,879 & 971 & 272 & 158 & 64.3 & 38.2 & 37.6 & 12.6 & 11.4 & 27.4 & 77.8 & 1.20 & 2.3 \\
\hline 1990 & 2,012 & 888 & 370 & 129 & 65.0 & 37.8 & 39.1 & 12.0 & 12.0 & 26.3 & 88.8 & 1.24 & 2.4 \\
\hline 1991 & 2,242 & 984 & 401 & 121 & 68.6 & 39.4 & 41.4 & 14.3 & 12.3 & 30.8 & n.a. & 1.23 & 2.2 \\
\hline 1992 & 2,519 & 1,054 & 506 & 171 & 75.1 & 43.7 & 45.4 & 15.4 & 14.0 & 37.5 & 80.1 & 1.25 & 2.6 \\
\hline 1993 & 2,747 & 1,159 & 466 & 143 & 84.1 & 49.3 & 51.3 & 19.5 & 16.5 & 44.3 & 80.1 & 1.24 & 2.6 \\
\hline 1994 & 3,352 & 1,277 & 520 & 146 & 85.2 & 51.2 & 53.5 & 21.1 & 19.4 & 39.4 & 81.8 & 1.24 & 2.3 \\
\hline 1995 & 3,552 & 1,432 & 562 & 149 & 89.3 & 54.6 & 56.5 & 24.6 & 21.7 & 49.3 & 88.4 & 1.25 & 2.3 \\
\hline 1996 & 4,212 & 1,690 & 623 & 168 & 90.9 & 56.7 & 57.7 & 27.0 & 23.6 & 55.9 & 91.4 & 1.28 & 2.2 \\
\hline 1997 & 4,872 & 2,126 & 678 & 191 & 90.9 & 58.1 & 56.0 & 25.9 & 23.3 & 65.6 & 91.9 & 1.26 & 2.1 \\
\hline 1998 & 5,283 & 2,385 & 770 & 217 & 90.0 & 56.0 & 56.8 & 23.8 & 22.8 & 79.8 & 89.7 & 1.28 & 2.1 \\
\hline 1999 & 6,352 & 2,722 & 803 & 232 & 88.7 & 53.7 & 55.4 & 23.7 & 20.4 & 84.0 & 88.1 & 1.30 & 1.4 \\
\hline 2000 & 8,340 & 3,164 & 923 & 224 & 95.3 & 60.1 & 57.2 & 24.8 & 22.0 & 84.1 & 116.4 & 1.30 & n.a. \\
\hline 2001 & 9,018 & 3,092 & 881 & 170 & 95.0 & 60.1 & 55.2 & 23.5 & 20.4 & 60.8 & 118.1 & 1.34 & n.a. \\
\hline 2002 & 7,302 & 2,640 & 700 & 157 & 96.6 & 60.4 & 56.1 & 20.8 & 19.8 & 57.7 & 112.0 & 1.39 & n.a. \\
\hline All & 75,263 & 31,213 & 10,137 & 3,171 & 84.0 & 51.7 & 50.8 & 20.5 & 18.5 & 54.8 & 95.1 & 1.25 & 2.2 \\
\hline
\end{tabular}


Table 2. Earnings announcement returns on mutual fund holdings. For each periodic mutual fund holdings report, we compute the average subsequent quarterly earnings announcement return: raw, market-adjusted, and benchmark-adjusted; and equal- and value-weighted across all holdings by fund. The characteristics benchmark return is the corresponding $5 \times 5 \times 5$ size, book-to-market, and momentum average earnings announcement return in the matched quarter. Momentum here is defined as the return in the past 4 earnings announcements. We annualize these returns (multiplying by four) and average across all funds within a year. Returns are Winsorized at the top and bottom one percent.

\begin{tabular}{|c|c|c|c|c|c|c|}
\hline \multirow[b]{2}{*}{ Year } & \multicolumn{3}{|c|}{ EW Earnings Announcement Alpha } & \multicolumn{3}{|c|}{ VW Earnings Announcement Alpha } \\
\hline & Return & MAR & BAR & Return & MAR & BAR \\
\hline 1980 & -0.09 & -0.49 & $\begin{array}{l}-0.15 \\
\end{array}$ & -0.09 & -0.44 & -0.03 \\
\hline 1981 & 0.78 & 0.61 & 0.15 & 1.17 & 1.02 & 0.52 \\
\hline 1982 & 1.38 & 0.38 & 0.54 & 1.39 & 0.47 & 0.54 \\
\hline 1983 & -0.85 & 0.00 & 0.05 & -0.96 & -0.09 & 0.01 \\
\hline 1984 & 1.49 & -0.06 & 0.40 & 1.65 & 0.05 & 0.41 \\
\hline 1985 & 1.09 & -0.42 & -0.07 & 1.39 & -0.14 & 0.08 \\
\hline 1986 & 1.93 & 0.46 & 0.49 & 2.26 & 0.75 & 0.68 \\
\hline 1987 & -2.19 & 0.19 & -0.62 & -2.30 & 0.35 & -0.69 \\
\hline 1988 & 0.17 & -0.01 & -0.40 & 0.32 & 0.14 & -0.31 \\
\hline 1989 & 0.05 & -0.45 & 0.21 & 0.18 & -0.33 & 0.25 \\
\hline 1990 & 1.86 & 0.71 & 0.22 & 2.00 & 0.76 & 0.23 \\
\hline 1991 & 1.37 & 0.80 & -0.10 & 1.24 & 0.60 & -0.17 \\
\hline 1992 & 1.80 & 0.65 & -0.04 & 1.76 & 0.58 & -0.09 \\
\hline 1993 & 0.80 & 0.84 & 0.00 & 0.80 & 0.82 & -0.11 \\
\hline 1994 & 0.92 & 0.30 & -0.17 & 1.01 & 0.39 & -0.23 \\
\hline 1995 & 2.46 & 0.92 & -0.07 & 2.53 & 0.98 & -0.07 \\
\hline 1996 & 2.53 & 1.67 & 0.21 & 2.72 & 1.87 & 0.23 \\
\hline 1997 & 3.51 & 1.32 & 0.13 & 3.62 & 1.40 & 0.08 \\
\hline 1998 & 1.43 & 0.42 & 0.12 & 1.54 & 0.44 & 0.01 \\
\hline 1999 & 3.04 & 2.67 & 0.56 & 3.29 & 2.95 & 0.81 \\
\hline 2000 & -1.26 & 0.12 & 0.73 & -1.31 & 0.20 & 0.80 \\
\hline 2001 & 1.58 & 0.48 & -0.55 & 1.53 & 0.50 & -0.65 \\
\hline 2002 & 1.08 & 0.90 & -0.33 & 1.41 & 1.18 & -0.14 \\
\hline Avg & 1.08 & 0.52 & 0.06 & 1.18 & 0.63 & 0.09 \\
\hline SD & 1.34 & 0.71 & 0.35 & 1.41 & 0.75 & 0.40 \\
\hline$[\mathrm{t}]$ & [3.9] & {$[3.5]$} & {$[0.8]$} & {$[4.0]$} & {$[4.0]$} & {$[1.1]$} \\
\hline
\end{tabular}


Table 3. Earnings announcement returns on mutual fund holdings: By fund characteristics. For each periodic mutual fund holdings report, we compute the average subsequent quarterly earnings announcement return: raw and benchmark-adjusted; and equal- and value-weighted across all holdings by fund. The characteristics benchmark return is the corresponding $5 \times 5 \times 5$ size, book-to-market, and momentum average earnings announcement return in the matched quarter. Momentum here is defined as the return in the past 4 earnings announcements. We annualize these returns (multiplying by four) and average across all funds by past performance quintile (past returns), investment objective (style), total market value of reported holdings (fund size), turnover, and incentive fee structure for each report date. For past returns, size, and turnover, quintiles go from lowest to highest. Past performance is defined based on the previous eight holdings reports for the corresponding definition of performance. Returns are Winsorized at the top and bottom one percent.

\begin{tabular}{|c|c|c|c|c|c|c|c|c|}
\hline & \multicolumn{4}{|c|}{ EW Earnings Announcement Alpha } & \multicolumn{4}{|c|}{ VW Earnings Announcement Alpha } \\
\hline & Return & [t] & BAR & [t] & Return & [t] & BAR & [t] \\
\hline Quintile & \multicolumn{8}{|c|}{ Panel A. Past Returns } \\
\hline 1 & 1.13 & [2.9] & -0.17 & {$[-1.5]$} & 1.24 & [3.3] & -0.09 & {$[-0.9]$} \\
\hline 2 & 1.20 & {$[3.2]$} & -0.08 & {$[-0.7]$} & 1.33 & [ 3.4] & -0.20 & {$[-1.5]$} \\
\hline 3 & 1.43 & {$[3.5]$} & -0.06 & {$[-0.6]$} & 1.30 & [ 3.3] & -0.05 & {$[-0.5]$} \\
\hline 4 & 1.37 & {$[3.4]$} & 0.01 & {$[0.1]$} & 1.45 & [ 3.7] & 0.07 & [ 0.6$]$ \\
\hline 5 & 1.47 & {$[3.4]$} & 0.25 & {$[2.1]$} & 1.51 & [ 3.3] & 0.10 & [0.6] \\
\hline $5-1$ & 0.34 & {$[2.8]$} & 0.43 & [3.3] & 0.27 & [1.6] & 0.19 & [ 1.3] \\
\hline Style & \multicolumn{8}{|c|}{ Panel B. Style } \\
\hline G & 1.32 & [3.3] & 0.13 & [ 1.2$]$ & 1.42 & [3.6] & 0.13 & [ 1.0$]$ \\
\hline G\&I & 1.23 & {$[3.7]$} & -0.08 & {$[-0.9]$} & 1.26 & [ 3.6] & -0.11 & {$[-1.0]$} \\
\hline I & 0.86 & {$[2.6]$} & -0.45 & {$[-2.7]$} & 0.92 & [ 2.8] & -0.44 & {$[-2.3]$} \\
\hline $\mathrm{G},<\mathrm{G} \& \mathrm{I}, \mathrm{I}>$ & 0.28 & [ 1.7] & 0.39 & [3.5] & 0.33 & [ 1.9] & 0.40 & [ 3.4] \\
\hline $\mathrm{G} \& \mathrm{I},<\mathrm{G}, \mathrm{I}>$ & 0.14 & {$[1.6]$} & 0.08 & {$[1.1]$} & 0.09 & [ 0.9] & 0.05 & [0.5] \\
\hline $\mathrm{I},<\mathrm{G}, \mathrm{G} \& \mathrm{I}>$ & -0.42 & {$[-2.8]$} & -0.47 & {$[-3.8]$} & -0.42 & {$[-2.4]$} & -0.45 & {$[-3.1]$} \\
\hline Quintile & \multicolumn{8}{|c|}{ Panel C. Size } \\
\hline 1 & 1.15 & {$[3.1]$} & -0.05 & {$[-0.6]$} & 1.25 & [3.4] & 0.01 & {$[0.1]$} \\
\hline 2 & 1.27 & [3.5] & 0.05 & {$[0.8]$} & 1.31 & [ 3.7] & 0.03 & [0.4] \\
\hline 3 & 1.23 & {$[3.2]$} & 0.01 & {$[0.1]$} & 1.35 & [ 3.6] & 0.06 & [0.6] \\
\hline 4 & 1.24 & {$[3.3]$} & 0.03 & {$[0.3]$} & 1.32 & [ 3.5] & 0.01 & {$[0.1]$} \\
\hline 5 & 1.26 & {$[3.4]$} & 0.02 & {$[0.2]$} & 1.38 & [ 3.8] & 0.04 & {$[0.4]$} \\
\hline $5-1$ & 0.11 & {$[1.4]$} & 0.07 & [ 1.1$]$ & 0.13 & [1.6] & 0.04 & [0.6] \\
\hline Quintile & \multicolumn{8}{|c|}{ Panel D. Turnover } \\
\hline 1 & 1.16 & [3.3] & -0.07 & {$[-0.8]$} & 1.28 & [ 3.7] & -0.03 & {$[-0.3]$} \\
\hline 2 & 1.10 & {$[3.0]$} & -0.11 & {$[-0.8]$} & 1.19 & [ 3.3] & -0.10 & {$[-0.8]$} \\
\hline 3 & 1.17 & {$[3.0]$} & -0.03 & {$[-0.3]$} & 1.21 & [ 3.1] & -0.07 & {$[-0.6]$} \\
\hline 4 & 1.26 & {$[3.1]$} & 0.04 & {$[0.3]$} & 1.34 & [ 3.3] & 0.04 & [0.3] \\
\hline 5 & 1.50 & {$[3.5]$} & 0.27 & {$[2.1]$} & 1.59 & [ 3.7] & 0.26 & [ 2.0] \\
\hline $5-1$ & 0.34 & {$[2.2]$} & 0.34 & [ 2.7] & 0.32 & [2.0] & 0.29 & [ 2.2] \\
\hline Fees & \multicolumn{8}{|c|}{ Panel E. Incentive Fees } \\
\hline Yes & 1.49 & {$[3.8]$} & 0.27 & [ 2.6] & 1.64 & [4.0] & 0.23 & [ [1.6] \\
\hline No & 1.27 & {$[3.4]$} & 0.08 & [ 1.3] & 1.37 & [ 3.7] & 0.10 & [ 1.4] \\
\hline Yes-No & 0.22 & [ 2.4] & 0.19 & [ 2.3] & 0.27 & [ 2.0] & 0.13 & [ 1.0$]$ \\
\hline
\end{tabular}


Table 4. Earnings announcement returns on mutual fund trades. For each periodic mutual fund holdings report, we compute the average subsequent quarterly earnings announcement returns: raw and benchmark-adjusted; and equal-weighted across weight increases, weight decreases, long weight increases and short weight decreases, first buys, last sells, and long first buys and short last sells by fund. The characteristics benchmark return is the corresponding $5 \times 5 \times 5$ size, book-to-market, and momentum average earnings announcement return in the matched quarter. Momentum here is defined as the return in the past 4 earnings announcements. We annualize these returns (multiplying by four) and average across all funds within a year. Returns are Winsorized at the top and bottom one percent.

\begin{tabular}{|c|c|c|c|c|c|c|c|c|c|c|c|c|}
\hline \multirow[b]{2}{*}{ Year } & \multicolumn{2}{|c|}{ Weight Increases } & \multicolumn{2}{|c|}{ Weight Decreases } & \multicolumn{2}{|c|}{ Increases-Decreases } & \multicolumn{2}{|c|}{ First Buys } & \multicolumn{2}{|c|}{ Last Sells } & \multicolumn{2}{|c|}{ First Buys-Last Sells } \\
\hline & Return & BAR & Return & BAR & Return & BAR & Return & BAR & Return & BAR & Return & BAR \\
\hline 1980 & -0.35 & -0.33 & -0.09 & -0.18 & -0.26 & -0.15 & -0.57 & -0.56 & -0.66 & -0.69 & 0.09 & 0.14 \\
\hline 1981 & 0.95 & 0.32 & 0.52 & -0.06 & 0.43 & 0.38 & 0.61 & -0.03 & -0.02 & -0.43 & 0.63 & 0.40 \\
\hline 1982 & 1.87 & 0.91 & 0.40 & -0.24 & 1.47 & 1.15 & 2.78 & 1.84 & 0.44 & -0.34 & 2.34 & 2.19 \\
\hline 1983 & -0.71 & 0.07 & -1.03 & 0.03 & 0.32 & 0.04 & -0.41 & 0.39 & -1.37 & -0.44 & 0.96 & 0.83 \\
\hline 1984 & 1.45 & 0.44 & 1.39 & 0.30 & 0.05 & 0.14 & 1.14 & 0.26 & 0.84 & 0.10 & 0.30 & 0.16 \\
\hline 1985 & 1.33 & 0.13 & 0.83 & -0.29 & 0.49 & 0.42 & 1.24 & 0.01 & 0.98 & -0.21 & 0.26 & 0.22 \\
\hline 1986 & 2.41 & 0.88 & 1.30 & 0.00 & 1.11 & 0.88 & 2.10 & 0.78 & 1.46 & 0.22 & 0.64 & 0.56 \\
\hline 1987 & -2.22 & -0.64 & -2.00 & -0.52 & -0.22 & -0.12 & -2.65 & -0.81 & -1.68 & -0.38 & -0.97 & -0.43 \\
\hline 1988 & 0.44 & -0.15 & -0.26 & -0.82 & 0.70 & 0.67 & 1.00 & 0.35 & -0.17 & -0.72 & 1.17 & 1.06 \\
\hline 1989 & 0.50 & 0.60 & -0.80 & -0.47 & 1.30 & 1.07 & 0.36 & 0.55 & -1.14 & -0.64 & 1.50 & 1.19 \\
\hline 1990 & 2.11 & 0.38 & 1.24 & -0.20 & 0.87 & 0.58 & 2.04 & 0.51 & 0.78 & -0.54 & 1.26 & 1.05 \\
\hline 1991 & 1.66 & 0.22 & 1.12 & -0.41 & 0.54 & 0.63 & 1.65 & 0.23 & 1.46 & -0.15 & 0.20 & 0.38 \\
\hline 1992 & 1.75 & -0.05 & 1.69 & -0.09 & 0.06 & 0.04 & 2.40 & 0.69 & 1.21 & -0.55 & 1.19 & 1.24 \\
\hline 1993 & 0.77 & 0.02 & 0.84 & -0.07 & -0.07 & 0.09 & 0.79 & 0.14 & 1.01 & 0.01 & -0.22 & 0.13 \\
\hline 1994 & 1.01 & -0.08 & 0.66 & -0.43 & 0.34 & 0.35 & 1.11 & 0.23 & 0.55 & -0.57 & 0.56 & 0.79 \\
\hline 1995 & 2.49 & -0.03 & 2.35 & -0.22 & 0.14 & 0.19 & 3.01 & 0.53 & 2.34 & -0.20 & 0.67 & 0.73 \\
\hline 1996 & 2.58 & 0.26 & 2.31 & 0.08 & 0.27 & 0.18 & 2.16 & 0.10 & 2.26 & 0.16 & -0.10 & -0.05 \\
\hline 1997 & 3.58 & 0.23 & 3.24 & -0.07 & 0.34 & 0.30 & 3.41 & 0.44 & 3.12 & -0.09 & 0.29 & 0.53 \\
\hline 1998 & 1.47 & 0.11 & 1.30 & 0.23 & 0.17 & -0.12 & 1.77 & 0.45 & 1.49 & 0.63 & 0.28 & -0.18 \\
\hline 1999 & 3.26 & 0.77 & 2.26 & -0.19 & 1.00 & 0.96 & 3.58 & 1.09 & 1.48 & -1.05 & 2.10 & 2.13 \\
\hline 2000 & -0.87 & 1.10 & -2.08 & -0.13 & 1.21 & 1.23 & -1.47 & 0.99 & -2.14 & -0.45 & 0.67 & 1.44 \\
\hline 2001 & 1.43 & -0.54 & 1.69 & -0.59 & -0.26 & 0.05 & 1.91 & -0.13 & 1.64 & -0.52 & 0.28 & 0.38 \\
\hline 2002 & 1.40 & -0.09 & 0.67 & -0.53 & 0.73 & 0.45 & 0.75 & -0.27 & 1.47 & 0.22 & -0.71 & -0.49 \\
\hline Avg & 1.23 & 0.20 & 0.76 & -0.21 & 0.47 & 0.41 & 1.25 & 0.34 & 0.67 & -0.29 & 0.58 & 0.63 \\
\hline SD & 1.35 & 0.45 & 1.34 & 0.27 & 0.51 & 0.42 & 1.51 & 0.55 & 1.35 & 0.38 & 0.79 & 0.71 \\
\hline$[\mathrm{t}]$ & {$[4.4]$} & [2.1] & [2.7] & {$[-3.8]$} & [4.4] & {$[4.6]$} & {$[4.0]$} & [2.9] & [2.4] & {$[-3.6]$} & [3.5] & [4.2] \\
\hline
\end{tabular}


Table 5. Earnings announcement returns on mutual fund trades: By fund characteristics. For each periodic mutual fund holdings report, we compute the average subsequent quarterly earnings announcement returns: raw and benchmark-adjusted; and equal-weighted across weight increases, weight decreases, long weight increases and short weight decreases, first buys, last sells, and long first buys and short last sells by fund. The characteristics benchmark return is the corresponding $5 \times 5 \times 5$ size, book-to-market, and momentum average earnings announcement return in the matched quarter. Momentum here is defined as the return in the past 4 earnings announcements. We annualize these returns (multiplying by four) and average across all funds by past performance quintile (past returns), investment objective (style), total market value of reported holdings (fund size), turnover, and incentive fee structure for each report date. For past returns, size, and turnover, quintiles go from lowest to highest. Past performance is defined based on the previous eight holdings reports for the corresponding definition of performance. Returns are Winsorized at the top and bottom one percent.

\begin{tabular}{|c|c|c|c|c|c|c|c|c|c|c|c|c|}
\hline & \multicolumn{2}{|c|}{$\begin{array}{c}\text { Weight } \\
\text { Increases }\end{array}$} & \multicolumn{2}{|c|}{$\begin{array}{c}\text { Weight } \\
\text { Decreases }\end{array}$} & \multicolumn{2}{|c|}{$\begin{array}{l}\text { Increases- } \\
\text { Decreases }\end{array}$} & \multicolumn{2}{|c|}{ First Buys } & \multicolumn{2}{|c|}{ Last Sells } & \multicolumn{2}{|c|}{$\begin{array}{c}\text { First Buys- } \\
\text { Last Sells }\end{array}$} \\
\hline & Ret & BAR & Ret & BAR & Ret & BAR & Ret & BAR & Ret & BAR & Ret & BAR \\
\hline Quintile & \multicolumn{12}{|c|}{ Panel A. Past Return } \\
\hline 1 & 1.27 & -0.04 & 0.70 & -0.61 & 0.08 & 0.10 & 1.47 & 0.25 & 0.90 & -0.37 & 0.69 & 0.63 \\
\hline 2 & 1.37 & -0.02 & 1.09 & -0.21 & 0.37 & 0.17 & 1.45 & 0.30 & 0.82 & -0.45 & 0.61 & 0.57 \\
\hline 3 & 1.38 & 0.05 & 1.26 & -0.05 & 0.24 & 0.27 & 1.47 & 0.05 & 0.91 & -0.24 & 0.35 & 0.58 \\
\hline 4 & 1.54 & 0.17 & 1.21 & -0.11 & 0.43 & 0.45 & 1.55 & 0.40 & 0.88 & -0.28 & 0.79 & 0.61 \\
\hline 5 & 1.48 & 0.33 & 1.27 & -0.01 & 0.56 & 0.51 & 1.34 & 0.36 & 0.79 & -0.46 & 0.48 & 0.63 \\
\hline $5-1$ & [ 1.5$]$ & [ 2.6] & [ 2.0] & [ 2.1] & [ 1.9] & [ 2.5] & {$[-0.5]$} & {$[0.4]$} & {$[-0.3]$} & {$[-0.2]$} & {$[-0.5]$} & {$[0.0]$} \\
\hline Style & \multicolumn{12}{|c|}{ Panel B. Style } \\
\hline G & 1.48 & 0.29 & 0.89 & -0.27 & 0.59 & 0.56 & 1.48 & 0.40 & 0.70 & -0.41 & 0.78 & 0.81 \\
\hline G\&I & 1.37 & 0.03 & 1.06 & -0.21 & 0.31 & 0.24 & 1.60 & 0.38 & 0.86 & -0.40 & 0.73 & 0.79 \\
\hline I & 0.97 & -0.35 & 0.77 & -0.47 & 0.20 & 0.12 & 1.20 & -0.04 & 0.94 & -0.32 & 0.27 & 0.28 \\
\hline $\mathrm{G},<\mathrm{G} \& \mathrm{I}, \mathrm{I}>$ & [ 1.8] & {$[3.8]$} & {$[-0.1]$} & {$[0.5]$} & [ 2.9] & [ 3.1] & {$[0.3]$} & [ 1.1] & {$[-0.7]$} & {$[-0.2]$} & [ 1.1] & [ 1.1] \\
\hline $\mathrm{G} \& \mathrm{I},<\mathrm{G}, \mathrm{I}>$ & [ 1.2] & {$[0.5]$} & [ 1.9] & [ 1.6] & {$[-0.8]$} & {$[-0.8]$} & [ 1.3] & [ 1.0] & {$[0.2]$} & {$[-0.2]$} & [ 0.7] & [ 0.9$]$ \\
\hline $\mathrm{I},<\mathrm{G}, \mathrm{G} \& \mathrm{I}>$ & {$[-2.7]$} & {$[-3.2]$} & {$[-1.1]$} & {$[-1.5]$} & {$[-1.5]$} & {$[-1.5]$} & {$[-1.2]$} & {$[-1.6]$} & {$[0.4]$} & [0.3] & {$[-1.1]$} & {$[-1.2]$} \\
\hline Quintile & \multicolumn{12}{|c|}{ Panel C. Size } \\
\hline 1 & 1.29 & 0.08 & 0.87 & -0.31 & 0.42 & 0.38 & 1.17 & 0.03 & 0.79 & -0.38 & 0.37 & 0.42 \\
\hline 2 & 1.38 & 0.16 & 0.95 & -0.22 & 0.44 & 0.38 & 1.46 & 0.40 & 0.92 & -0.26 & 0.54 & 0.65 \\
\hline 3 & 1.41 & 0.17 & 0.90 & -0.26 & 0.51 & 0.43 & 1.55 & 0.42 & 0.92 & -0.24 & 0.63 & 0.66 \\
\hline 4 & 1.39 & 0.18 & 0.95 & -0.25 & 0.45 & 0.44 & 1.57 & 0.46 & 0.84 & -0.28 & 0.73 & 0.73 \\
\hline 5 & 1.41 & 0.16 & 0.91 & -0.28 & 0.50 & 0.44 & 1.44 & 0.33 & 0.56 & -0.62 & 0.88 & 0.95 \\
\hline $5-1$ & [1.3] & [ 1.1] & {$[0.4]$} & {$[0.2]$} & [ 0.7] & {$[0.6]$} & [ 1.4] & [ 1.6$]$ & {$[-1.0]$} & {$[-1.2]$} & [ 1.8$]$ & [ 1.9] \\
\hline Quintile & \multicolumn{12}{|c|}{ Panel D. Turnover } \\
\hline 1 & 1.30 & 0.07 & 0.88 & -0.33 & 0.42 & 0.39 & 1.21 & 0.14 & 0.66 & -0.50 & 0.55 & 0.64 \\
\hline 2 & 1.26 & 0.02 & 0.84 & -0.32 & 0.41 & 0.34 & 1.20 & 0.18 & 0.63 & -0.54 & 0.57 & 0.72 \\
\hline 3 & 1.33 & 0.14 & 0.97 & -0.19 & 0.37 & 0.33 & 1.47 & 0.37 & 0.99 & -0.11 & 0.48 & 0.48 \\
\hline 4 & 1.45 & 0.20 & 0.81 & -0.34 & 0.64 & 0.54 & 1.52 & 0.36 & 0.64 & -0.45 & 0.88 & 0.81 \\
\hline 5 & 1.60 & 0.37 & 0.94 & -0.26 & 0.65 & 0.63 & 1.67 & 0.50 & 0.80 & -0.38 & 0.87 & 0.88 \\
\hline $5-1$ & [1.7] & [ 2.1] & {$[0.4]$} & {$[0.4]$} & [ 1.6$]$ & [ 1.7] & [ 1.4] & {$[1.2]$} & {$[0.5]$} & {$[0.5]$} & {$[0.9]$} & {$[0.7]$} \\
\hline Fees & \multicolumn{12}{|c|}{ Panel E. Incentive Fees } \\
\hline Yes & 1.72 & 0.50 & 0.86 & -0.28 & 0.86 & 0.78 & 1.76 & 0.74 & 0.67 & -0.39 & 1.09 & 1.12 \\
\hline No & 1.42 & 0.22 & 0.96 & -0.17 & 0.46 & 0.39 & 1.51 & 0.41 & 0.83 & -0.27 & 0.68 & 0.68 \\
\hline Yes-No & [ 2.3] & [ 2.3] & {$[-0.7]$} & {$[-0.8]$} & [ 1.9] & [ 1.9] & {$[0.8]$} & [1.1] & {$[-0.6]$} & {$[-0.5]$} & [ 0.9] & [ 1.0] \\
\hline
\end{tabular}

